\title{
Revitalising Cooperative Values in Indonesian Educators for a Professional Learning Community
}

\author{
C. Pheeney \\ Universitas Pendidikan Indonesia \\ Bandung, Indonesia \\ Griffth University \\ Australia \\ christineida@ozemail.com.au
}

\begin{abstract}
Over 700 distinct indigenous communities form today's Indonesia. Their historical coming together was built upon five strategic principles, known as Pancasila. The Pancasila are collectively represented by the phrase and goal 'Unity in Diversity'. Indonesia's Ministry of Education directs teachers to create learning opportunities to develop a national character so that students learn how to live lives that characterize unity in diversity. Over the decades, the education system has encountered complex political influences and increased impacts of globalization. Unfortunately, a by-product of these encounters has been development of a false dichotomy: traditional cooperative values central to community daily living, relegated to personal arenas, and isolated practice evident in professional arenas. This study describes a workshop undertaken in Subang District of West Java, Indonesia, aimed to revitalize traditional cooperative values, as the basis for a professional learning community. Research promotes the engagement of various stakeholders in professional dialogue therefore the interaction of teachers, teacher educators (from Indonesia's Education University), and the district governance was facilitated, at the workshop. Traditional community cooperation, commonly known as 'gotong royong' was explored for application to professional cooperation. Exploration included mentoring, transparency, and application of cooperative values within workshop activities. The teachers interacted as a community to initiate response to community identified educational problems. The teachers' reflections describe that these grassroots interactions, focused on professional cooperation, combined with administrative support would be beneficial in developing national character, in and through education.
\end{abstract}

Keywords, professional cooperation, gotong royong, teacher agency.

\section{INTRODUCTION}

Indonesia was formed through the coming together of over 700 distinct indigenous communities. The founding of the nation was built upon five strategic principles, known as Pancasila. The Pancasila are collectively represented by the phrase and goal 'Unity in Diversity'. In working towards nation building, the Indonesian Ministry of Education directs teachers to create learning opportunities, which develop national character for living unity in diversity.

Indonesian Teachers, like their international colleagues, are frequently called to respond to new policies and initiatives in pursuit of national education system goals. New curriculums [1], teacher accreditation protocols [2], changes related to research and technology
[3], focus on competencies [4], and national standardized student achievement [5] are some of the externally introduced elements impacting teacher's daily activities. In order to respond to mandates, teachers are sent to numerous trainings in regional centers. Observation of teachers following their return from trainings shows isolated, independent behaviour as they struggle to face challenges alone. Sadly, current teacher behaviour as a group, does not reflect the national character of unity in diversity that historically brought together the diverse population and allowed sustainability of the indigenous communities. In dealing with change, it appears that a false dichotomy has been assumed. This dichotomy has relegated cooperative values, previously integral to all community daily living, to the personal arena. Thus isolation and independence take over in professional practice. Comprehensive application of the national character goals requires recognition of the teachers as learners who are given learning opportunities that foster holistic living and the interdependent practice for unity in diversity in the professional environment.

This paper reports on a workshop instigated in discussions at Universitas Pendidikan Indonesia by Social Science (FPIPS) colleagues about current teacher behaviours being incongruent to both traditional cooperative values and the goals of unity in diversity. Following those discussions, the Faculty Dean proposed development of a workshop to revitalize cooperative values with teachers in Subang, West Java. International research findings on teacher learning were reviewed and used to develop practical strategies. The findings are summarized in this paper, followed by the methodology for the workshop. Teacher responses and discussion of the workshop activities are presented to provide a reference point of activities undertaken in revitalizing cooperative values for the professional learning community of educators. Consideration of future support potentials and research opportunities concludes this paper.

\section{A. International Research relating to teacher learning}

Recognition of teacher learning needs in responding to change, is the subject of much international research. Findings by Keddie, Mills and Pendergast [5] show that change prescribed through various policies and organizational structures can problematically impact teacher agency levels. In order to maintain teacher agency Datnow [6] argues that teachers must be active in change. Furthermore, Hargreaves [7, p 288] argues that inclusive change and reform processes that engage teachers' 
knowledge and commitments are more likely to increase teachers' professional involvement in school improvement. Hargreaves proposes that 'support systems of training, mentoring, time and dialogue' are essential.

The idea of mentoring as a vehicle for teachers' professional development has been promoted by numerous researchers [8] [9] [10] [11]. Bieler and Fink [12] suggest mentoring within a relational discussion context, where integration of current and past experiences and knowledge - school practice, university courses, extra-curricular influences - will enable construction of meaningful teaching and learning; and that in this interaction, reflection and critical discourse about daily practice flows. Bieler and Fink [12] describe further benefits of mentoring as being the integration of the teacher's self, as both teacher and learner; and supportive care and practice, which lead to individual and collective autonomy and agency.

Alongside engaging teachers in mentoring, Lonergan, Mooney Simmie and Moles [13 p 107] suggest the engagement of all education stakeholders, including: school principals, teacher educators, students, administrators, parents, academics and policy makers. These education stakeholders, along with preservice and inservice teachers are essential. These researchers state that in dialogue members can 'weave collaboratively together to construct new insights and understandings'. Likewise, Fullan [14 p 189] asserts that 'working through the complexities of change until we get shared meaning and commitment is the only way to get substantial improvement'. In looking at logistics, both large and small networks are beneficial for the generation of new ideas and ongoing support. Hargreaves [7] calls for practice to be a 'culture of collaboration' suggesting that this will facilitate participation in knowledge-making and assertive interactions.

\section{B. Indigenous Indonesian Community Living and Learning}

A 'culture of collaboration', as described above, is reminiscent of traditional cooperative mentoring evident in indigenous Indonesian groups. This pattern of collaboration was utilized to sustain the community and to respond to environmental change. While known by various names in regional languages, the national language of Indonesia assigns the words "gotong royong" to the concept of "participatory collective action and mutual cooperation' [15] or synergy [16]. Gotong-royong is literally translated as 'sharing the burden'. This 'sharing the burden' is appropriated to use of local resources, and manifests itself in community living customs and cooperative characteristics. Study of indigenous cultural customs across the archipelago reveals how universally esteemed gotong royong is, while being expressed through unique customs, from the remarkably diverse environments where the people live [17].

In looking toward the future, researchers $[15,16,18]$ call for gotong-royong to be tapped into and revived for adult learning and community based management within current agendas for decentralization of administration.

In summary, analysis of international research findings relating to teacher learning and the Indonesian context show mentoring or cooperative collaboration as an appropriate strategy in working towards teacher agency, professional development/problem solving and living holistically (applying core values in personal and professional life). Further, fostering inclusive collaboration to work towards a shared goal is congruent to the ideals of unity and diversity. Revitalizing cooperation values to support the teachers as learners, as well as members of a professional community is needed.

\section{WORKSHOP DESIGN AND METHOD}

These congruent findings from international and Indonesian research became the theoretical basis to the workshop activities. It was considered that revitalizing gotong royong or cooperative values in teachers would foster behaviour reflective of the national character goal of unity in diversity. Therefore, stimulus recalling traditional community customs was planned to engage teachers in the analysis of cooperative practice. Subsequently activities requiring participating teachers to identify and work towards a collective professional goal were designed to strengthen teacher agency. Support was given through prompts to ensure the transference of cooperative elements experienced in the activity to cooperative professional behaviours. In applying cooperative values to professional goals the workshop aimed to foster cooperation values needed to initiate a functional professional learning community. Problem identification and problem solving activities were developed to instigate critical dialogue, leading to problem solving and teacher agency. Reflection questions were developed to help teachers realize a sense of solidarity and commitment to the pursuit of a professional learning community. This paper will now discuss further details of the workshop design and development.

\section{A. Workshop Activities}

The workshop design was broken down into 4 key learning foci. These were: 1. Stimulus material - get participants thinking about the importance of cooperation. This involved use of a story and unpacking the story for today's relevance; 2. Building awareness and analysis of the building blocks of cooperation - This involved use of photographs and discussion relating to a community wide cooperative project; 3 . Engaging participants - During this time in the workshop participants were to be given opportunity to voice their professional challenges and provided with scaffolds to work together on cooperative problem solving projects; 4. Reflecting on activities Participants were asked to consider their own actions and the benefits of cooperative professionalism and a professional learning community. Each of the foci will now be explained further.

\section{1) Workshop Foci 1: Stimulus Material}

To facilitate the starting point of recalling traditional cooperative values and some of the obstacles to living cooperatively, a 'story' was used. The story selected is a light-hearted parable of a mouse facing the introduction of a mousetrap to the farmyard. The mouse calls for help from other farmyard residents - a chicken, a goat, and a cow. These three, in their own way, decide not to respond to the mouse with any definitive action to remove the 'mouse's problem'.

However, the story ends with dramatic impact to the lives of the chicken, goat and cow. After the presentation 
of the story, teachers were asked questions such as: 'how do you respond when someone tells you a problem? What are the problems in your professional world? What would be a cooperative response?' After providing some time to give thought to these questions, the workshop proceeds to support teachers to transfer cooperative community life attributes within the second workshop foci.

2) Workshop Foci 2: Building Awareness and Analysis

In order to consider "how do we develop a cooperative response?" in problem solving, photos were used. (These were of a catering project for a community wedding the workshop presenter had recently attended). The photos were used to stimulate some analysis of the attributes present in traditional cooperation (or gotong royong). These attributes were categorised into 4 aspects: 1 . Mentoring; 2. Transparency; 3. Outworking of Cooperation values; and 4. Working towards a goal.

Through showing these photo slides, the workshop presenter aimed to engage participants in recalling their own experiences and then building on these. Therefore, the workshop discussion was designed to prompt analysis expanding the attributes to consider:

1. Mentoring - dynamics of multi-age members with varying levels of experience working together in skill building to complete a task

2. Communicating with Transparency - while working towards a collective goal, there is an opportune time to share challenges personally experienced, and hear other peoples' experiences, gathering mental, emotional and social support to face challenges and build good character

3. Outworking of Cooperation values - while undertaking a task, members work in community: being patient, humble, kind, loyal, disciplined, acting justly, being thankful and celebrative, active in peacemaking, and considering one another as members of a loving family.

4. Working towards a goal - the goal needs to be clearly defined: be specific, measurable, achievable, resource appropriate and time specific.

\section{3) Workshop Foci 3: Engaging Participants}

In working towards teacher motivation to cooperate professionally educational research success stories were relayed, pointing out that in these stories, mastery was found to reside in the diverse group, with members benefiting from shared expertise and experiences.

In order to foster a sense of connection between the workshop members and awareness of the variety of expertise present, teachers were asked to stand up if they related to the different characteristic presented within slides. These characteristics included: gender, age groups, cultural groupings, professional role, and statements about cooperative beliefs.

From this point the workshop was designed to engage participants in listing their professional problems and democratically selecting one of these and plan a response together. The workshop team modelled group problem ranking and then participants were invited to form groups of 8 to 15 and provided with problem ranking materials (peanuts and worksheet to list problems and then allocate priority, these were to be tallied to determine that groups focus) and scaffolding worksheet to be completed which prompted incorporation of cooperative attributes covered in Foci 2 of workshop. The workshop was designed with 20 minutes of professional problem solving group work. In this time, workshop facilitators would rove around groups and assist or prompt as needed. At the end of the group work a few groups were to be requested to share their responses.

\section{4) Workshop Foci 4: Reflection}

The final focus of the workshop was designed to provide participants with time to reflect on their activities and the benefit of teacher professional cooperation. This activity was facilitated with posting of posters around the perimeter of the workshop venue with specific questions. Participants were encouraged to provide thought or comment on at least 3 of these within a 10-minute timeframe, with opportunity to move around.

Following this the workshop would be closed with short encouraging remarks to continue to revitalise traditional cooperation within today's era in the professional arena.

\section{WORKSHOP PARTICIPANTS}

In corresponding to research findings and assertions that both small and large networks are necessary, 250 teachers were invited to participate in a workshop. Subang Region was selected because of its overtly public focus on cooperation. This region is active in valuing cooperation through extra-curricular activities; focus on family habits of cooperation and even has public monuments promoting cooperation. A mixture of school principals and teachers were selected for the workshop with $70 \%$ from primary schools and 30\% from junior high schools. Subang Region is comprised of 30 districts, including both urban and rural areas. The heads of those districts were requested to nominate 4 or 5 members to join the workshop.

Also Subang's proximity to UPI makes it an ideal pilot project to explore deepening professional community to include the university in dialogue with future support options for both pre-service and in service teachers.

\section{WORKSHOP PARTICIPATION AND RESEARCH METHODOLOGY}

With Subang district and UPI FPIPS cooperation, the workshop took place on the $19^{\text {th }}$ of August 2015. Teacher responses to planned activities brought about the unique collaborations and data of this specific group of teachers. The method of studying the teachers' behaviour and perspectives was qualitative, through gathering of responses and observations. These are described with inclusion of some quotations and photos from their activities.

Of the 250 invited teachers, 231 attended. Teacher participation was voluntary and collection of data was through obtaining permissions within registration process from the participants. 


\section{WORKSHOP ACTIVITY RESULTS AND DISCUSSION}

Overall the participants engaged in activities described in workshop methodology above. The interrelated foci worked towards teacher professional cooperation as a learning community. Tangible results of this interaction are evident in data collected from problem ranking, group problem solving and reflection activities. Description of the overall flow of the workshop is provided with these specific activities given more in depth presentation of concrete data. It is noted because of the large number of participants, not all discussion and responses can be included here.

Teachers were quick to contribute informal spoken responses relating to stimulus material (in Foci \#1) of the cooperation parable. They provided gestures to acknowledge common cooperation experiences of community living. They showed that they related to experiences in professional realm where they had shared or responded to a problem similar to the parable animals. Similarly, informal gestures and responses to were given to photo stimulus of highlighting attributes of cooperation (foci 2).

The standing in agreement or identification of personal characteristics was another informal gesture that teachers actively participated in. Facial expressions came to show wonder at their diversity and delight in their unified identity, illustrated in Figure 1.

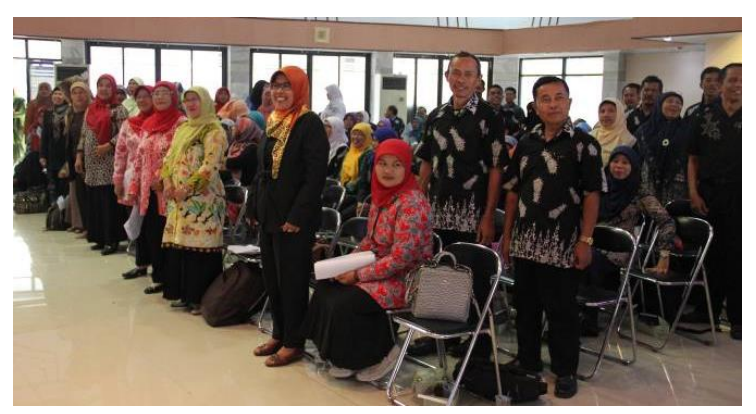

Fig. 1. Teachers movement responses related to experiences

The enthusiasm continued to increase within the problem ranking and group problem solving activities as described below.

\section{A. Engaging Problem Ranking Activity}

Teacher responses to problem ranking activity within groups were collected. There were 18 groups of between 8 to 15 members. In asking for list of 4 to 8 problems, each group developed unique lists. Corresponding to this each group list shows unique data relating to ranking of the problems Table 1. Shows a sample of group response with list of problems and group ranking of the problem. In this sample group we see "student's not interested in reading" as the highest rank problem. This problem is explored in the following section. Figure 2. shows a sample group undertaking the problem ranking activity with peanuts. Participants actively engaged in this activity.
TABLE I. SAMPLE GROUP RESPONSE LISTING AND RANKING PROFESSIONAL PROBLEMS

\begin{tabular}{|l|l|}
\hline \multicolumn{2}{|l|}{$\begin{array}{l}\text { List 4- } 8 \text { Professional Problems that you face as a teacher, } \\
\text { work in groups and undertake problem ranking activity }\end{array}$} \\
\hline Differences in student's character \& competencies & 4 \\
\hline Difficulty in motivating student's passion to learn & 9 \\
\hline $\begin{array}{l}\text { Students are reluctant to share their ideas in group } \\
\text { discussions }\end{array}$ & 8 \\
\hline Hard to get students to answer teachers' questions & 5 \\
\hline Students not interested in reading & 11 \\
\hline Students are disruptive to each other's concentration & 3 \\
\hline Students are not very communicative with groups & 8 \\
\hline Students don't sit still or can't focus & 6 \\
\hline
\end{tabular}

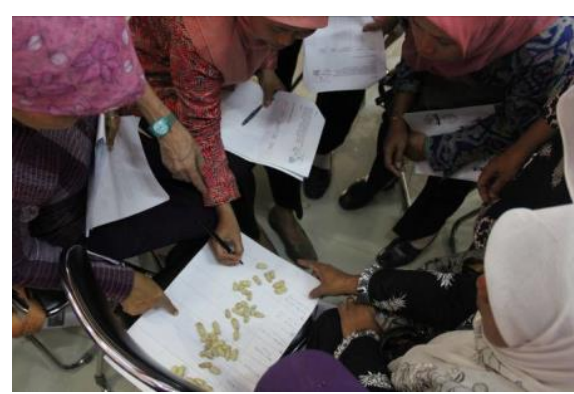

Fig. 2. Participants engaged in Problem Ranking Activity

Compilation of all professional problems listed by participants is listed in table 2 below. Details of the number of groups that listed that problem and total number of votes recorded as well as number of groups choosing that problem to discuss are recorded. It is noted that some groups did not record their votes, only recording which of their problems they had ranked highest. Also it is noted that some problems were listed but didn't receive a vote.

TABLE II. COMPILATION OF PROFESSIONAL PROBLEMS AND FREQUENCY

\begin{tabular}{|l|l|l|l|}
\hline Listed Problems & $\begin{array}{l}\text { No. Grp } \\
\text { listing }\end{array}$ & $\begin{array}{l}\text { Total } \\
\text { votes }\end{array}$ & $\begin{array}{l}\text { Grp } \\
\text { focus }\end{array}$ \\
\hline Students no motivation to do homework & 6 & 36 & $* * *$ \\
\hline Students not motivated to in class/learn & 10 & 73 & $\begin{array}{l}* * * * * \\
*\end{array}$ \\
\hline Late arrivals or absenteeism to school & 7 & 23 & \\
\hline Rubbish not placed in bin & 2 & 10 & \\
\hline No interest in reading & 7 & 52 & $* * * *$ \\
\hline No rapport with subject area teachers & 5 & 23 & \\
\hline Unkempt uniforms & 1 & 2 & \\
\hline Disrespectful talk / Bad behaviour & 9 & 43 & $*$ \\
\hline Students not understanding lesson & 5 & 25 & $*$ \\
\hline Students not comprehending & 2 & 8 & \\
\hline Students with psycho social challenges & 5 & 23 & \\
\hline Hyperactive students/ disruptive & 8 & 27 & $*$ \\
\hline Assessment system & 1 & 1 & \\
\hline $\begin{array}{l}\text { Efforts to get students cooperating \& } \\
\text { autonomous/ Group work challenges }\end{array}$ & 9 & 47 & \\
\hline $\begin{array}{l}\text { In sufficient parent support/community } \\
\text { interaction }\end{array}$ & 4 & 25 & $* *$ \\
\hline Facilities, funding, Govt. support, library & 3 & & $*$ \\
\hline Making selective response to globalisation & 1 & & \\
\hline Use of ICT & 1 & & \\
\hline Teacher Competencies & 2 & & \\
\hline School Leadership & 2 & 7 & \\
\hline $\begin{array}{l}\text { Lack of professional sharing after trainings } \\
\text { attended by representative }\end{array}$ & 1 & & \\
\hline
\end{tabular}

In looking at these collated results we see "Lack of student motivation" was listed as the priority topic for six of the groups. Analysis of all group responses shows that student behaviour and attitude is seen as the biggest 
problem area. Further analysis shows lack of motivation and interest in learning by both students and community. Looking at overall statistics is useful to consider correlations between the problems. This highlights how critical it is to draw all stakeholder groups into dialogue to form a strategy to work on shared goals together. It is hoped that this activity of listing problems fosters further participant reflection as well as building dialogue amongst the professional learning community.

\section{B. Collegial Mentoring in Problem Solving}

In this phase of the workshop participants were asked to remember and apply the attributes of cooperation to address their own professional problems (as described in previous activity). Workshop presenters provided slides of these aspects and a group example outworking these to a professional problem. Figure 3 shows photo of slide show and professional round table discussion. Additionally, this activity was scaffolded with a worksheet to direct attention to include all the elements informally included in cooperation as undertaken in traditional cultural customs.

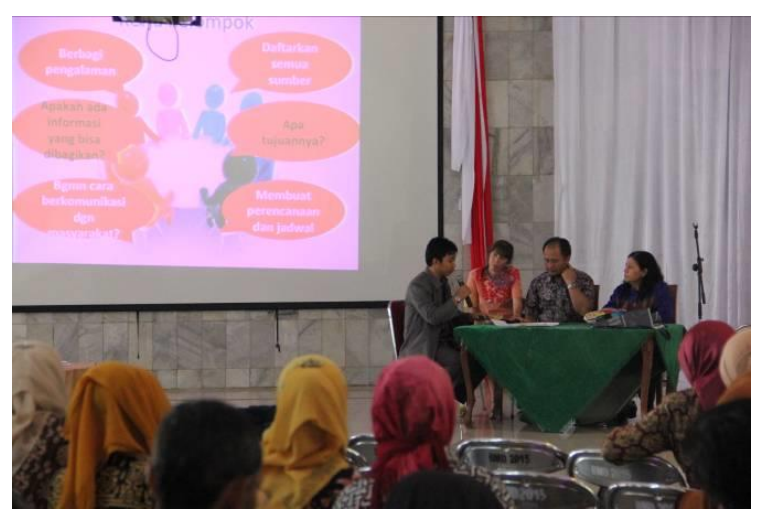

Fig. 3. Nurturing Professional Learning Community

\section{Professional Problem Solving/Learning Community}

After witnessing the workshop presenters' conduct an example learning community discussion, participants were asked to work in their groups to address the problem they had identified as significant. Group responses were very different according to the problem they were addressing and the participants within the group. A sample response is presented in Table 3.

The teachers' response and planning in this task conveys a strong sense of responsibility to contribute to the development of their students and schools.

Generally, the groups developed practical action plans and considered a diverse list of resources to utilise. However, some groups did not clearly define time frames or measurements of success to easily follow up on. It would have been beneficial to have more assistants helping prompt groups while they were working. After working in small groups, the large group was bought back together. A few groups were selected to present their discussions. At this time further consolidation of the instructions were given. It is hoped that this will assist the participants as they go back to their districts in their schools, if they choose to make use of this strategy/format.
TABLE III. SAMPLE RESPONSE TO GROUP PROBLEM SOLVING TASK

\begin{tabular}{|c|c|c|c|c|}
\hline $\begin{array}{l}\text { Activity - } \\
\text { clearly an } \\
\text { achieved th }\end{array}$ & $\begin{array}{l}\text { iplete an } \\
\text { dentify } 1 \\
\text { goal (mer }\end{array}$ & $\begin{array}{l}\text { on plan for the goal } \\
\text { you will determin } \\
\text { es of success). }\end{array}$ & $\begin{array}{l}\text { ntified. } \\
\text { vhether }\end{array}$ & $\begin{array}{l}\text { ate goal } \\
\text { u have }\end{array}$ \\
\hline Goal - Stude & t interest in re & ding increases & & \\
\hline $\begin{array}{l}\text { Measures } \\
\text { stories they }\end{array}$ & $\begin{array}{l}\text { he success- } \\
\text { ve read }\end{array}$ & tudents collate an inter & sting res & \\
\hline Objective & Activity & Resources Needed & Time & $\begin{array}{l}\text { Next } \\
\text { Step }\end{array}$ \\
\hline $\begin{array}{l}\text { Increase } \\
\text { student } \\
\text { interest in } \\
\text { reading }\end{array}$ & $\begin{array}{l}\text { Teacher } \\
\text { shares } \\
\text { personal } \\
\text { motivation } \\
\text { for reading }\end{array}$ & $\begin{array}{l}\text { Select a favourite story; } \\
\text { Table/resume list } \\
\text { favourite books with } \\
\text { factors } \\
\text { character etc) }\end{array}$ & $\begin{array}{l}4 \times 35 \\
\text { min les; } \\
\text { Week } 1\end{array}$ & $\begin{array}{l}\text { Set task } \\
\text { of sts } \\
\text { listing a } \\
\text { favourit } \\
\text { e book }\end{array}$ \\
\hline $\begin{array}{l}\text { Increase } \\
\text { student } \\
\text { engageme } \\
\text { nt in } \\
\text { reading }\end{array}$ & $\begin{array}{l}\text { Make book } \\
\text { resume as } \\
\text { a class - } \\
\text { read } \\
\text { together \& } \\
\text { analyse;gr } \\
\text { oup then } \\
\text { individual } \\
\text { work }\end{array}$ & $\begin{array}{l}\text { Book Resume chart } \\
\text { whiteboards/worksheet; } \\
\text { Wide selection of } \\
\text { books; Letter to parents } \\
\text { about the plan;Parent } \\
\text { involvement }\end{array}$ & $\begin{array}{l}4 \quad x \quad 35 \\
\text { min les; } \\
\text { Read10 } \\
\text { mins per } \\
\text { day }\end{array}$ & $\begin{array}{l}\text { Develop } \\
\text { regular } \\
\text { schedule } \\
\text { for class } \\
\text { reading } \\
\& \\
\text { h'work }\end{array}$ \\
\hline $\begin{array}{l}\text { Increase } \\
\text { student } \\
\text { dialogue/ } \\
\text { about } \\
\text { reading }\end{array}$ & $\begin{array}{l}\text { Student } \\
\text { sharing } \\
\text { about their } \\
\text { reading }\end{array}$ & $\begin{array}{l}\text { Rewards for reading } \\
\text { and sharing about } \\
\text { books; } \\
\text { Many books }\end{array}$ & $\begin{array}{l}4 \times 35 \\
\text { min les; } \\
\text { read } 10 \\
\text { mins per } \\
\text { day }\end{array}$ & $\begin{array}{l}\text { Promote } \\
\text { competit } \\
\text { ion to } \\
\text { complet } \\
\mathrm{e} \text { book } \\
\text { list } \\
\text { resume }\end{array}$ \\
\hline $\begin{array}{l}\text { Increase } \\
\text { class } \\
\text { produced } \\
\text { reading } \\
\text { material }\end{array}$ & $\begin{array}{l}\text { Sts } \\
\text { develop } \\
\text { stories \& } \\
\text { publish } \\
\text { personal } \\
\text { books } \\
\end{array}$ & $\begin{array}{l}\text { Makes example book; } \\
\text { Paper, Colour pencils; } \\
\text { Continued } \\
\text { communication with } \\
\text { parents }\end{array}$ & $\begin{array}{l}4 \quad x \quad 35 \\
\text { min les; } \\
\text { read10 } \\
\text { mins per } \\
\text { day }\end{array}$ & $\begin{array}{l}\text { Class } \\
\text { library, } \\
\text { make } \\
\text { resume }\end{array}$ \\
\hline
\end{tabular}

\section{Teacher reflections related to Professional} Cooperation

In order to consolidate the idea of revitalising traditional gotong royong values within professional activities, the final focus of the workshop involved reflection. Participants were asked to take time to reflect on their own thinking about the benefits and practicalities of professional cooperation. Eight questions were placed on small charts around the venue. teachers were asked to share their current thoughts about professional cooperation on 3 of the charts within 10-minute period. Figure 4 shows photos of teachers in process of responding, walking around room
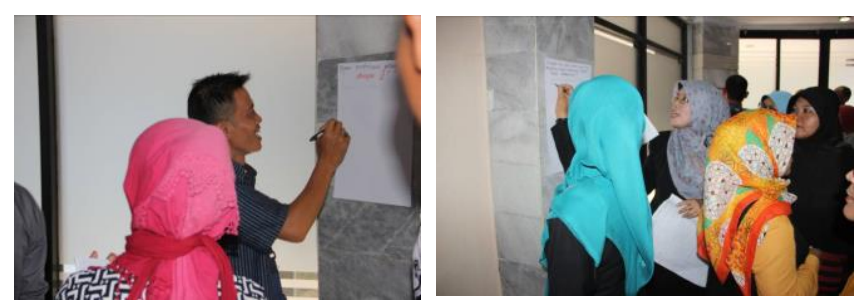

Fig. 4. Teachers making Reflections

The variety of questions was provided to assist with teachers making holistic reflections of impact of professional cooperation and develop a sense that their choices bring about consequences. Even though time available made it possible for any teacher to visit about 3 of the charts during the workshop, teachers were encouraged to discuss the questions further in future meetings within their districts. (Participants were given a copy of the questions and all materials in a workbook). The teachers' responses to reflective open ended questions are provided in Table 4 below. All responses are provided to assist with understanding the participants' perspectives and application thoughts of professional cooperation. 
TABLE IV. TEACHER REFLECTIONS ON PROFESSIONAL COOPERATION

\begin{tabular}{|l|}
\hline What does professional cooperation look like? \\
\hline There is a solidarity in breaking down educational problems \\
\hline Care to workmates/colleagues \\
\hline Mutual trust between friends \\
\hline Harmony is created \\
\hline Enjoyment \\
\hline Sharing work to solve the problems that happen at school \\
\hline Strengthened a sense of family or belonging \\
\hline Creates harmony in all members of the school community \\
\hline Mutual contribution and sharing \\
\hline Mutual removal of weaknesses colleagues \\
\hline What is the community benefit if teachers cooperate? \\
\hline The teacher behaviour can be an example to the community \\
\hline It could extend with the community joining \\
\hline The community has greater trust in the school \\
\hline
\end{tabular}

The community has greater trust in the school

Sharing of information is more effective, with teacher and school information in harmony

Students will develop cooperative character

Community life becomes easier

The life of the community is unified

The community will feel supported

What is the benefit to teachers individually if they cooperate?

The teacher becomes better at teaching

The teacher gets to work together with group

Teachers can do something about changing their teaching/learning

The teacher can respond to problems better

The teacher solves problems appropriately and quickly

Increased knowledge on how to problem solve

The experience and knowledge of the teacher increases

What is the benefit to students if teachers cooperate?

Students will increase in knowledge and skills

They can follow the example of the teachers behaviour

Students are motivated to follow their example

Students are more creative

Learning is more interesting

Students are more active and engage in their learning

Students are enthusiastic to learn

The quality of the school will increase in the public's eyes

Passion for learning

A follow on will be learning, with good results

Students interested to be diligent in their learning

What is the benefit to Indonesia as a nation, if teachers professionally cooperate?

Increased quality of Education in Indonesia

Increases good feeling about education

Increase unity and solidarity

Work becomes easier

The nation will prosper and progress

Produces nation wide generation that is professional

Strengthens unity

All problems with be efficiently solved

Mutual awareness of each other

Develop community that is faithful and loyal

It can bring about policy implementation

Brings outcomes for educators that are better and progressive

Creates quality human resources

National goals of Education will be achieved

Shows unity and solidarity

How do we engage cooperation to see unity in diversity?

Don't discriminate with negative treatment to others

Teach students about regional songs of Indonesia

Encourage Unity and solidarity

Don't discriminate between teachers of different ethnic, religious or cultural groups

Don't give preferential treatment to friends but be professional to all

Work together

Be respectful of differences

Treat students according to background

What does teacher professional cooperation feel like?

Compassion and Family feeling between us as friends both in positions of above and below

Family

\begin{tabular}{|l|}
\hline Peaceful \\
\hline Empathic \\
\hline Loving \\
\hline Unifying \\
\hline Team building \\
\hline Brings healing and wholeness \\
\hline More beautiful \\
\hline Problems solved! \\
\hline What is the benefit if teachers cooperate - in the International Sphere? \\
\hline Increase unity of our (human) race and between nations \\
\hline Knowledge of other cultures \\
\hline Come to know other national cultures and them knowing us \\
\hline Increased global awareness of Indonesia \\
\hline Demonstrate Nationalism \\
\hline Teachers have a broader experience \\
\hline Increase relationships that are mutually beneficial and share the load. \\
\hline
\end{tabular}

The teacher reflections show a strong valuing of professional cooperation as a concept. They listed multiple benefits of this professional cooperation to all levels and stakeholders of the community. Unity and solidarity was regularly listed as a benefit in the diverse groups being impacted. Also evident in the teachers' reflections is a sense of agency and enjoyment in the process and dialogue they were engaged in.

\section{CONCLUSION}

The teachers embraced the idea of incorporating traditional community cooperation attributes in their professional roles. The teachers became actively involved in workshop activities. As they shared openly the problems they encounter as professionals, they took the posture of a community of learners ready to glean from each other's expertise while contributing their own ideas, experiences and reflections. It was observed that in revitalising cooperation, synergy was released. This resulted in creative strategies to respond to problems and challenges. Simultaneously, solidarity, teacher agency and respect for diverse stakeholders increased. There was flowing dialogue and cooperation amongst Subang Regional Council and Indonesian's University of Education (UPI) and teachers.

Use of small and large group activities in the workshop was beneficial in creating highly interactive working groups and solidarity as a community. In order to maintain a sense of agency, future small group meetings at schools have been proposed and can be timetabled to suit participants. To ensure

momentum and access to a larger group's expertise, scheduling regular interval, whole group meetings would be beneficial. Potentially existing meetings between teachers at the district level could include activities to support more dialogue, which is vital for optimal function as a community of learners. Additionally, the exploration of digital tools could be useful in facilitating the participatory engagement of both small and large groups, while also assisting with self-directed inquiries. Exploration of tools, strategies, groupings and frequency of meetings with this community should be encouraged and supported as the professional learning community develops. Fostering the complete revitalisation of Cooperation in the teacher's professional role is likely to support positive individual and shared identities. This in turn would create more accountability, which extends and enhances whole community learning. 
Revitalisation of cooperation values offers first an opportunity for teachers as individuals to enact a holistic paradigm of unity in diversity. Second, in supporting the teachers as a professional learning community, it is anticipated that observance of Indonesian national character unity in diversity will be enabled. Simultaneously this national goal or ideal becomes both a reality and a strategy to respond individually and collectively to environmental and political changes and challenges for implementation of Pancasila, making possible a creative and sustainable Indonesia. Therefore, focussed efforts from teachers at grass roots level and administrative support are needed to prioritise and see benefit from revitalisation of cooperation.

In this initial exploratory study, it is considered that participants felt free to engage honestly. This was evident in their provision of open responses. Their participation within the workshop was voluntarily and anonymous. It is noted that this workshop produced of a unique set of data related to the district and participants involved. As the workshop was undertaken in one regional area and focussed on teacher professional development activities, it is a possible that other groups and locations could yield variations. It is recommended that revitalisation of cooperative values be explored further. First with this community as they put into long term practice their plans and strengthen their community. Second, exploration with other groups and locations is also recommended. Potentially this could serve to connect them and extend the community of learners and therefore release further synergy with exponential benefits. Further studies providing a more extensive focus could consider items including but not limited to:

- Long-term management of Strategies for teacher learning and reflexivity.

- Development of strategies to engage all education stakeholders a professional community of learners (scheduling guidelines, instructional prompts, ideas and examples of supporting frameworks for school, working group and regional group interactions: frequency and focus of interactions)

- Development of social media tools and networks to support the community of learners Development of a social media professional code of conduct.

\section{ACKNOWLEDGEMENTS}

Thanks to the teachers who participated in this research and to FPIPS and Subang Regional Council enabling this workshop to take place and supporting teachers' attendance.

\section{REFERENCES}

[1] Kristiansen S, Pratikno. Decentralising Education in Indonesia. International Journal of Educational Development. 2006;26(5):513-531.

[2] Firman H, Tola B. The Future of Schooling in Indonesia. [Internet]. 1st ed. Journal of International Cooperation in Education; 2008. Available from: http://home.hiroshimau.ac.jp/cice/11-1Firman_Tola.pdf

[3] Kementerian Pendidikan dan Kebudayaan. Kurrikulum 2013, Bahan Uji Publik. Jakarta, Indonesia: http://www.slideshare.net/wdarminto/bahan-uji-publik-kurikulum2013-15556710; 2012.

[4] Young M. A Case of the Global-Local Dialectic: Decentralization and Teacher Training in Banten, Indonesia [Doctor of Philosophy thesis]. Florida State University; 2010.

[5] Keddie A, Mills M, Pendergast D. Fabricating an identity in neo-liberal times: performing schooling as 'number one'. Oxford Review of Education. 2011;37(1):75-92.

[6] Datnow A. Collaboration and contrived collegiality: Revisiting Hargreaves in the age of accountability. Journal of Educational Change. 2011;12(2):147-158.

[7] Hargreaves A. Inclusive and exclusive educational change: emotional responses of teachers and implications for leadership. School Leadership \& Management. 2004;24(3):287-309.

[8] Hargreaves A, Fullan M. Mentoring in the New Millennium. Theory Into Practice. 2000;39(1):50-56.

[9] Sundli L. Mentoring-A new mantra for education?. Teaching and Teacher Education. 2007;23(2):201-214.

[10] Turk R. Get on the Team: An Alternative Mentoring Model. In: Scherer M, ed. by. A Better Beginning Supporting and Mentoring New Teachers. 1st ed. Virginia: Association for Supervision and Curriculum Development; 1999. p. 172-189.

[11] Halford J. Easing the Way for New Teachers. In: Scherer M, ed. A Better Beginning: Supporting and Mentoring New Teachers. 1st ed. Virginia: Association for Supervision and Curriculum Development; 1999. p. 13-17.

[12] Bieler D, Fink L. Strengthening new teacher agency through holistic mentoring. English Journal. 2013;102(3):23-32.

[13] Lonergan J, Mooney Simmie G, Moles J. Mentoring to reproduce or change discourse in schools. International Journal of Mentoring \& Coaching in Education. 2012;1(2):104-119.

[14] Fullan M. The new meaning of educational change. New York: Teachers College Press; 2001.

[15] Flor A. Environmental Communication and People's Participation: Lessons Learned in Five Natural Resources Management Projects. 1st ed. Los Baños: SEAMEO-SESARCA; 2002.

[16] Napitupulu W. Creating Change Agents for Building Lifelong Learning Networks. In: Singh M, ed. Institutionalising lifelong learning: Creating conducive environments for adult learning in the Asian context [Internet]. 2nd ed. Hamburg: UNESCO Institute for Learning.; 2004 p. 153-158. Available from: http://10.1016/S0738 -0593(03)00081-6

[17] Pheeney C, Malihah E, Supriatna M, Kartadinata S. Impact of UPI Cultural Market in developing ethnopedagogic paradigms. Bandung: Dikti Research; 2015.

[18] Widianingsih I, Morrell E. Participatory Planning in Indonesia. Policy Studies. 2007;28(1):1-15. 